\title{
Y3.At7:22/TEM-425
}

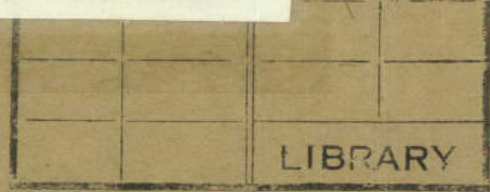

P A S T O R A P E A K N E.

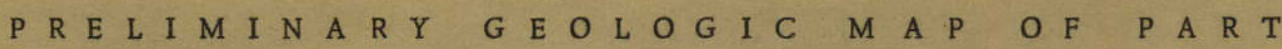

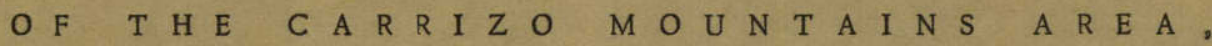

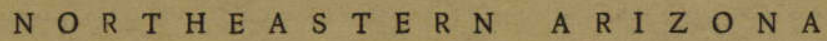

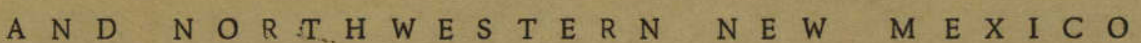

RECENED

\section{AUG $2: 1952$}

Trace Elements Memorandum Report 425 THESTERTVETH

UNITED STATES DEPARTMENT OF THE INTERIOR GEOLOGICAL SURVEY

\section{FEB 111991}

metadc1393426 



\section{UNITED STATES \\ DEPARTMENT OF THE INTERIOR \\ GEOLOGICAL SURVEY \\ WASHINGTON 25. D.C.}

AEC - $182 / 3$

August 10,1952

Dr. Phillip L. Merritt, Assjstant Director

Division of Rav Materials

U. S. Atomic Energy Commission

P. O. Box 30, Ansonia Station

New York 23, New York

Dear Phil:

Transmitted herewith for your information and distribution are six copies of Trace Elements Memorandum Report 425, "Pastora Peak $\mathrm{NE}$, preliminary geologic map of part of the Carrizo Mountains area, northeastern Arizona and northwesterm New Mexico," by J. D. Strobell, Jr., August 1952.

This map is transmitted in advance of publication, in order to assist Conmission and Survey personnel in their search for uranium deposits in the area. It shows geology, roads, drainage, meridians and parallels, triangulation stations, and air-photo centers and wing points. It is in very preliminary form, partiy incomplete, and not edited for publication.

We plan to combine this map with the 15 remaining $7 \frac{1}{2}$ minute quadrangles of the area that have been or soon will be transmitted to you. After the 16 quadrangles are redrafted on a reduced scale as one map, we will submit a copy to $\mathrm{Mr}$. Hosted for approval to publish in the Survey's Oil and Gas Map Series.

Sincerely yours,

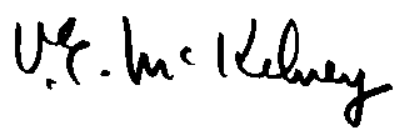

In W. H. Bradley 
UNCLASSIFIED

Geology - Mineralogy

This document consists of 2 pages, plus 1 figure.

Series A

\title{
UNITED STATES DEPARTMENT OF THE INTERIOR
}

GEOLOGICAL SURVEY

\author{
PASTORA PEAK NE, PRELIMINARY GEOLOGIC MAP OF PART \\ OF THE CARRIZO MOUNTAINS AREA, N.ORTHEAS.TERN ARIZONA. AND \\ NORTHWESTERN NEW MEXICO*
}

By

J. D. Strobell, Jr

A ugust 1952

Trace Elements Memorandum Report 425

This preliminary report is distributed without editorial and technical review for conformity with official standards and nomenclature. It is not for public inspection or quotation.

*This report concerns work done on behalf of the Division of Raw Materials of the U. S. Atomic Energy Commission 
American Cyanamid Company, Watertown . . . . . . . . . . . . . . 1 Argonne National Laboratory . . . . . . . . . . . . . . . . . . . 1 Atomic Energy Commission, Washington. . . . . . . . . . . . 2 Carbide and Carbon Chemicals Company, Y-12 Area . . . . . . . . . . 1 Colorado Raw Materials Office (F. H. MacPherson). . . . . . . . . . . 2 Division of Raw Materials, Grand Junction. . . . . . . . . . . . 6 Division of Raw Materials, Grants . . . . . . . . . . . . . . . 1 Division of Raw Materials, Denver . . . . . . . . . . . . . . . 1 Division of Raw Materials, Hot Springs. . . . . . . . . . . . . 1

Division of Raw Materials, New York. . . . . . . . . . . . 6

Division of Raw Materials, Salt Lake City . . . . . . . . . . . 1

Division of Raw Materials, Richfield . . . . . . . . . . . . . 1

Division of Raw Materials, Butte. . . . . . . . . . . . . 1

Division of Raw Materials, Washington . . . . . . . . . . . 3

Dow Chemical Company, Pittsburg . . . . . . . . . . . . 1

Technical Information Service, Oak Ridge. . . . . . . . . . 6

U. S. Geological Survey:

Mineral Deposits Branch, Washington . . . . . . . . . . . . 1

Geochemistry and Petrology Branch, Washington ............ 1

Geophysics Branch, Washington . . . . . . . . . . . . . . . 1

Alaskan Geology Branch, Washington . . . . . . . . . . . 1

Fuels Branch, Washington . . . . . . . . . . . . 3

V.E. McKelvey, Washington. ................. 1

L.R. Page, Denver ...................... . . . 2

Ro $P$. Fischer, Grand Junction . . . . . . . . . . . . . 2

J.F. Smith, Jr., Denver. . . . . . . . . . . . . . 2

C. B. Read, Albuquerque. ................... 1

A. H. Koschmann, Denver . . . . . . . . . . . . . 1

E. H. Bailey, San Francisco . . . . . . . . . . . . . . 1

A.F. Shride, Tucson . . . . . . . . . . . . . . 1

R.J. Roberts, Salt Lake City. . . . . . . . . . . . . . 1

W. A. Fischer, Washington ................... 1

TEPCO, Washington . . . . . . . . . . . . . . . . 4

(Including master) 


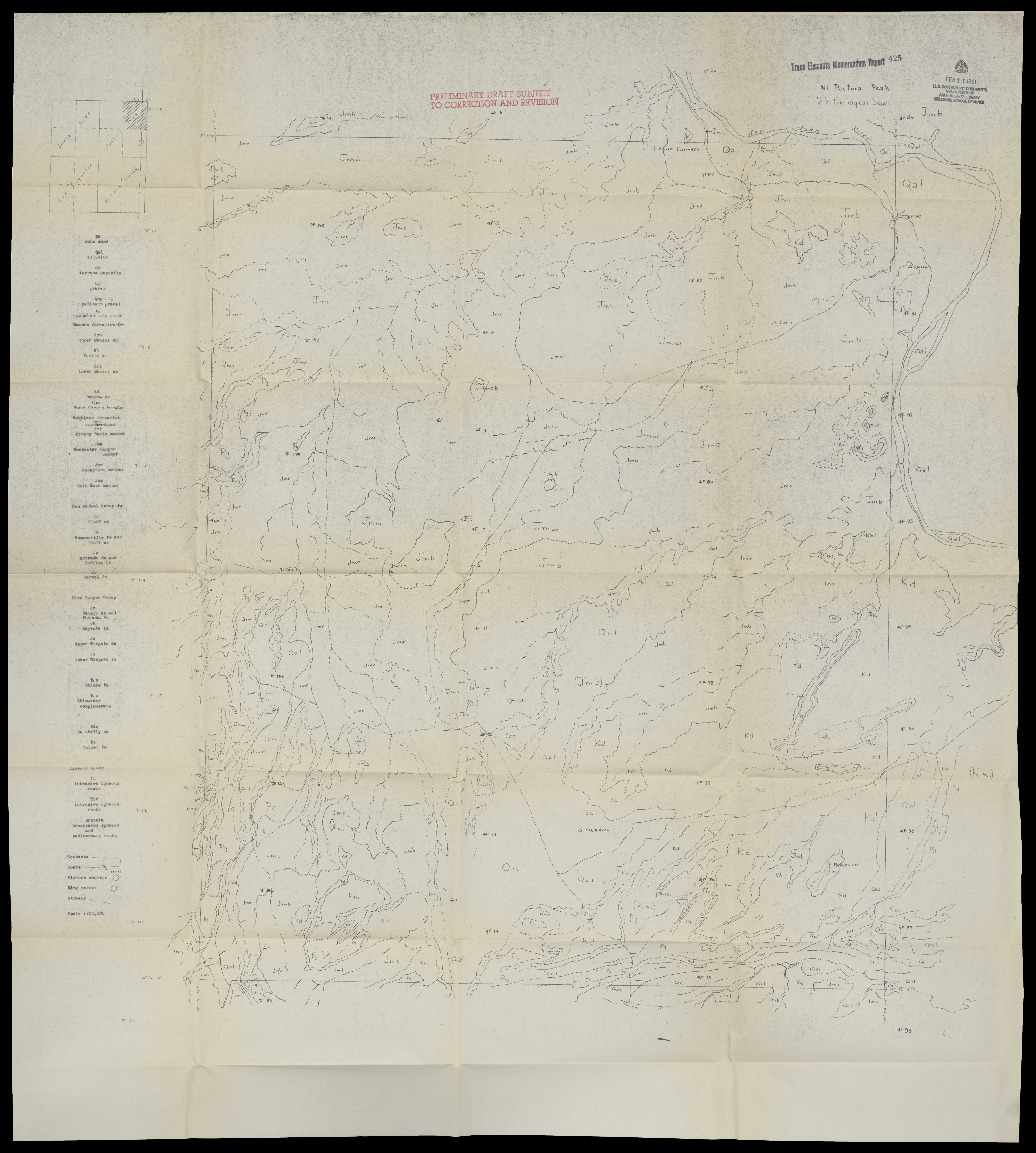




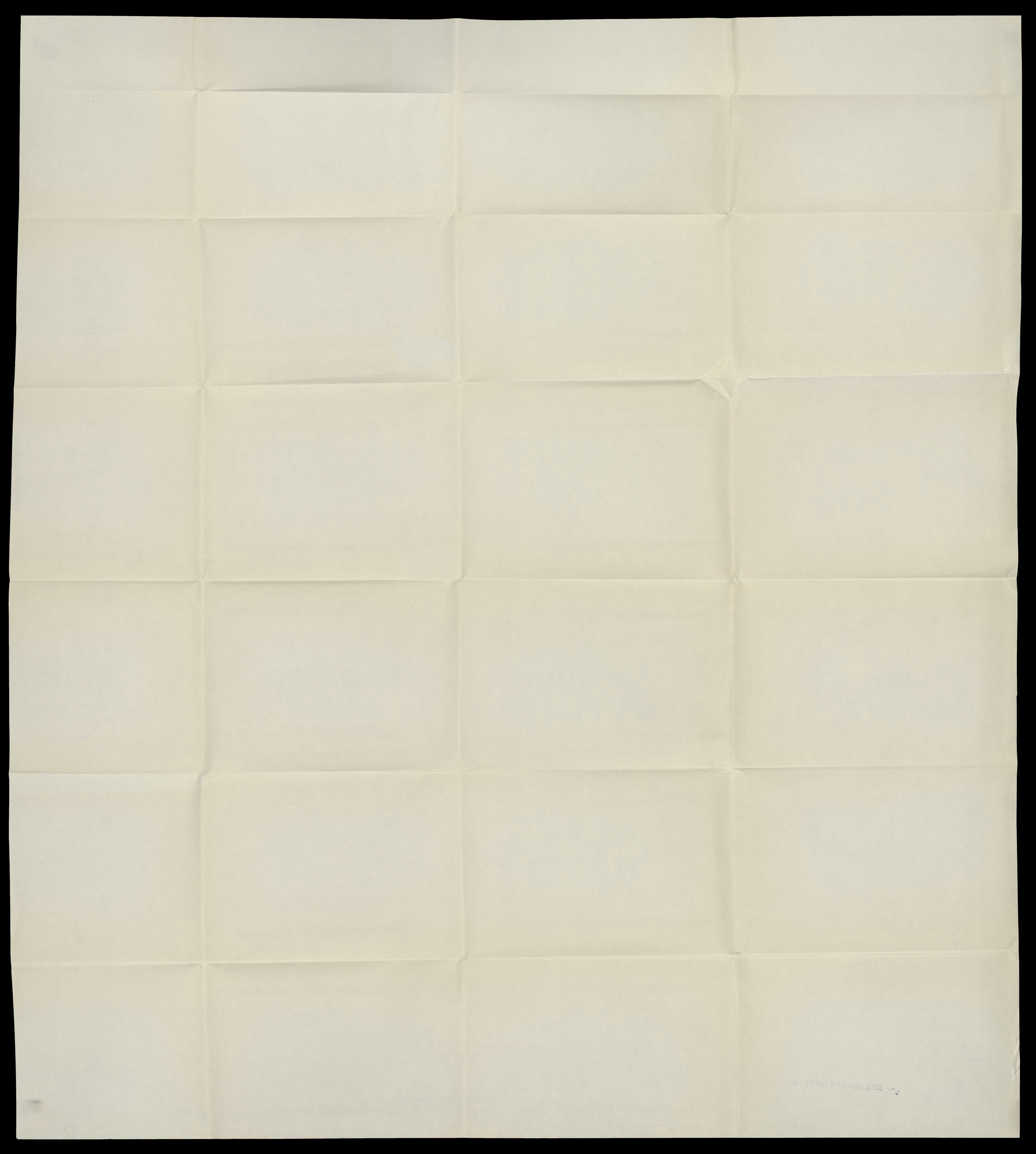



